\title{
Spectroscopic properties and photodynamic effects of new lipophilic porphyrin derivatives: Efficacy, localisation and cell death pathways
}

\author{
Gabriela Kramer-Marek ${ }^{\text {a,b,* }}$, Carlos Serpa ${ }^{\text {c }}$, Agnieszka Szurko ${ }^{\text {a,d }}$, Maria Widel ${ }^{\text {d }}$, \\ Aleksander Sochanik ${ }^{e}$, Miroslaw Snietura ${ }^{\text {f }}$, Piotr Kus ${ }^{g}$, Rui M.D. Nunes ${ }^{\text {c }}$, \\ Luis G. Arnaut ${ }^{\mathrm{c}}$, Alicja Ratuszna ${ }^{\mathrm{a}}$ \\ ${ }^{a}$ A.Chelkowski Institute of Physics, University of Silesia, Uniwersytecka 4, 40-007 Katowice, Poland \\ ${ }^{\mathrm{b}}$ Department of Tumour Biology, Maria Sklodowska-Curie Memorial Cancer Centre and Institute of Oncology, 44-100 Gliwice, Poland \\ ${ }^{\mathrm{c}}$ Chemistry Department, University of Coimbra, 3004-535 Coimbra, Portugal \\ d Department of Clinical and Experimental Radiobiology, Maria Sklodowska-Curie Memorial Cancer Centre and Institute of Oncology, \\ 44-100 Gliwice, Poland \\ e Department of Molecular Biology, Maria Sklodowska-Curie Memorial Cancer Centre and Institute of Oncology, 44-100 Gliwice, Poland \\ ${ }^{\mathrm{f}}$ Department of Tumour Pathology, Maria Sklodowska-Curie Memorial Cancer Centre and Institute of Oncology, 44-100 Gliwice, Poland \\ ${ }^{\mathrm{g}}$ Institute of Chemistry, University of Silesia, 40-007 Katowice, Poland
}

Received 26 July 2005; received in revised form 7 December 2005; accepted 11 December 2005

Available online 21 February 2006

\begin{abstract}
Photodynamic therapy (PDT) and photodynamic diagnostics (PDD) of cancer are based on the use of non-toxic dyes (photosensitisers) in combination with harmless visible light. This paper reports physicochemical properties, cell uptake, localisation as well as photodynamic efficiency of two novel lipophilic porphyrin derivatives, suitable for use as PDT sensitisers. Both compounds are characterised by high quantum yield of singlet oxygen generation which was measured by time-resolved phosphorescence. Photodynamic in vitro studies were conducted on three cancer cell lines. Results of cell survival tests showed negligible dark cytotoxicity but high phototoxicity. The results also indicate that cell death is dependent on energy dose and time following light exposure. Using confocal laser scanning microscopy both compounds were found to localise in the cytoplasm around the nucleus of the tumour cells. The mode of cell death was evaluated based on the morphological changes after differential staining.

In summary, good photostability, high quantum yield of singlet oxygen and biological effectiveness indicate that the examined lipophilic porphyrin derivatives offer quite interesting prospects of photodynamic therapy application.
\end{abstract}

(C) 2006 Elsevier B.V. All rights reserved.

Keywords: Photodynamic therapy; Singlet oxygen; Photosensitisation; Apoptosis; Necrosis

\section{Introduction}

Photodynamic therapy (PDT) is a relatively novel and promising anticancer therapy based on combined use of a photosensitising agent and visible or near-infrared light [1]. It can be very effective in destroying tumour cells and

\footnotetext{
* Corresponding author. Present address: Instytut Fizyki, Uniwersytet Śląski, Uniwersytecka 4, 40-007 Katowice, Poland. Tel.: +48 3235921 05; fax: +48322588431

E-mail address: kramer_gabriela@yahoo.co.uk (G. Kramer-Marek).
}

side effects in healthy tissues are relatively low $[2,3]$. Generally, PDT is based on photoactivation of a sensitiser taken up by targeted (i.e., cancer) cells. Two types of reaction can occur after photoactivation of the photosensitiser. The first involves generation of free radicals like superoxide anion, $\mathrm{O}_{2}^{-}$(type I); the second produces singlet molecular oxygen ${ }^{1} \mathrm{O}_{2}\left({ }^{1} \Delta_{\mathrm{g}}\right)$ (type II), possibly the main species responsible for oxidising neighbouring molecules [4,5]. Highly reactive oxygen species formed within cell membrane, cytoplasm or organelles lead to peroxidative reactions causing damage to DNA and other molecules and finally resulting in 
cell death [6]. PDT can rapidly induce apoptosis of targeted cells although precise mechanisms underlying this process are not completely characterised $[7,8]$. A second mode of cell death observed in PDT is necrosis [9].

Porphyrins and porphyrin-related macrocycles are among the sensitisers most frequently used in PDT. Once inside the cell, they bind to apolar endocellular matrices such as lysosomes, mitochondria or/and plasma membranes. The site of porphyrin action depends on its polarity and, to some extent, is cell-line dependent $[7,10]$.

Among the first-generation photosensitisers the most popular is Photofrin II, widely used in clinical practice $[11,12]$. However, its applications remain limited because Photofrin II is a complex mixture with low extinction coefficient in the red spectral region. This implies administration of relatively large amounts of this drug in order to obtain satisfactory phototherapeutic response. In consequence, due to high drug accumulation, patients have to stay several days out of sunlight to avoid sunburn reactions. These drawbacks have stimulated the search for photosensitising agents with improved optical and pharmacokinetic characteristics.

Two synthetic porphyrin derivatives: 5-(4-hydroxyphenyl)-10,15,20-tritolylporphyrin and 5-(4-hexadecyloxyphenyl)-10,15,20-tri-pyridylporphyrin were synthesised in our laboratory. The structures of these compounds are shown in Fig. 1 and for convenience they will be referred to as C16-TTP and TPYR-PP, respectively. They have been shown to possess suitable chemical purity, relatively high absorption coefficient in the phototherapeutic windows $(600-800 \mathrm{~nm})$, as well as high quantum yield of singlet oxygen generation that favour their use as potential photodynamic agents.

In this paper, we describe the synthesis and photochemical properties of these porphyrins. Particular attention is given to the time-resolved singlet oxygen phosphorescence as a measure of C16-TTP and TPYR-PP singlet oxygen quantum yield $\left(\Phi_{\Delta}\right)$. The results of cytotoxicity and phototoxicity studies as well as cellular localisation and the effect of radiation dose for cell death induction in different tumour cell lines are also presented.

\section{Materials and methods}

\subsection{Materials}

5-(4-Hydroxyphenyl)-10,15,20-tritolylporphyrin (C16TTP) was synthesised as described elsewhere [13]. Briefly, $50 \mathrm{mg}$ of hydroxyphenylporphyrin, $50 \mathrm{mg}$ of cetyl bromide, $2 \mathrm{~g}$ of anhydrous potassium carbonate and $20 \mathrm{ml}$ of dimethyl formamide (DMF) were placed in a flask and stirred at room temperature (RT) for $5 \mathrm{~h}$. The reaction progress was checked using TLC (silica gel/chloroform). One hundred millilitre of water was added to the reaction and the resulting mixture was extracted three times using ethyl acetate $(3 \times 20 \mathrm{ml})$. The extracts were washed five times with water, dried over anhydrous $\mathrm{MgSO}_{4}$ and evaporated. The raw product was washed with $30 \mathrm{ml}$ of methanol. Precipitated porphyrin was separated and air-dried. The product was purified twice on a silica gel column using hexane (to remove excess cetyl bromide) and eluted with chloroform.

Yield: $75 \% .{ }^{1} \mathrm{H}$ NMR $\left(500 \mathrm{MHz}, \mathrm{CDCl}_{3}\right): \delta=8.83(\mathrm{~m}$, $8 \mathrm{H}, \beta-\mathrm{H}), 8.06,7.51(\mathrm{dd}, 12 \mathrm{H}, \mathrm{ArH}), 8.07,7.21(\mathrm{dd}, 4 \mathrm{H}$, $\mathrm{ArH}), 4.21$ (t, $\left.2 \mathrm{H}, \mathrm{O}-\mathrm{CH}_{2}\right), 2.67\left(\mathrm{~s}, 9 \mathrm{H}, \mathrm{ArCH}_{3}\right), 1.94$ (q, $2 \mathrm{H}), 1.62(\mathrm{q}, 2 \mathrm{H}), 1.36-1.10(\mathrm{~m}, 22 \mathrm{H}), 0.85(\mathrm{t}, 3 \mathrm{H})$, -2.79 (s, 2H, NH); ESI-MS: $m / z=897(100 \%,(\mathrm{M}+$ $\left.\mathrm{H})^{+}\right) ; \mathrm{C}_{63} \mathrm{H}_{68} \mathrm{~N}_{4} \mathrm{O}$ : Calcd. C, 84.33; H, 7.64; N, 6.24. Found: C, 83.95; H, 7.74; N, 6.58\%.

5-(4-Hexadecyloxyphenyl)-10,15,20-tri-pyridylporphyrin (TPYR-PP) was synthesised using the procedures partly described elsewhere [14]. Briefly, $2.12 \mathrm{~g}$ of $p$-hexadecyloxybenzaldehyde, $1.82 \mathrm{~g}$ of 4-pyridylcarboxyaldehyde and $1.25 \mathrm{~g}$ of pyrrole were heated for $30 \mathrm{~min}$ in boiling propionic acid. After $24 \mathrm{~h}$, an excess of acid was distilled out and the mixture was extracted with ethyl acetate. Then, extract was dried with anhydrous $\mathrm{MgSO}_{4}$. The end-products were separated by column chromatography and the compound of interest eluted.

Yield: $15 \% .{ }^{1} \mathrm{H}$ NMR $\left(500 \mathrm{MHz}, \mathrm{CDCl}_{3}\right): \delta=8.14,9.02$ $\left(\mathrm{dd}, 12 \mathrm{H}_{\mathrm{pyr}}, J=5,4 \mathrm{~Hz}\right), 8,78,8.94(\mathrm{dd}, 4 \mathrm{H}, \beta-\mathrm{H}), 8.82$ (bs, $4 \mathrm{H}, \beta-\mathrm{H}), 8.07,7.27$ (dd, $4 \mathrm{H}, \operatorname{ArH}, J=8.4 \mathrm{~Hz}), 4.23$ (t, $2 \mathrm{H}), 1.96(\mathrm{q}, 2 \mathrm{H}), 1.45(\mathrm{q}, 2 \mathrm{H}), 1.40-1.20(\mathrm{~m}, 22 \mathrm{H}), 0.76$

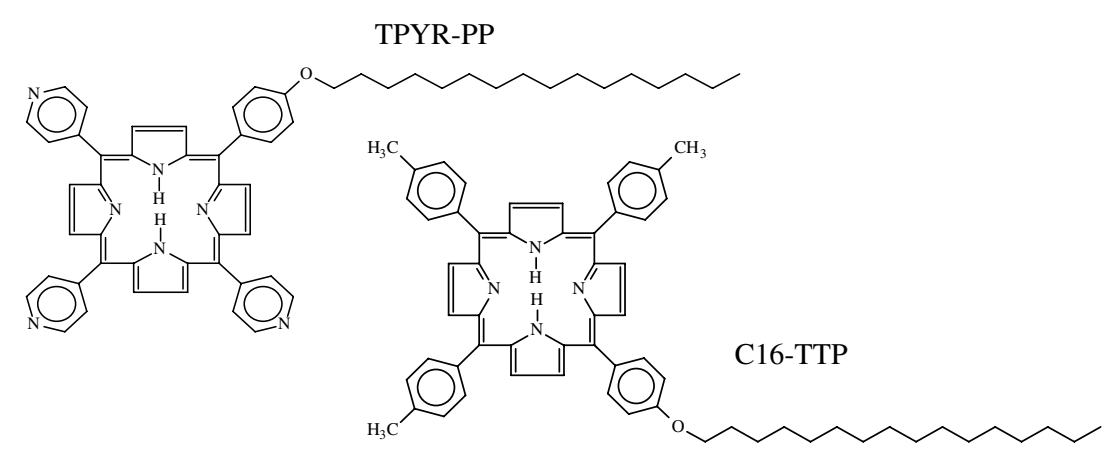

Fig. 1. The structure of 5-(4-hexadecyloxyphenyl)-10,15,20-tri-pyridylporphyrin (TPYR-PP) and 5-(4-hydroxyphenyl)-10,15,20-tritolylporphyrin (C16TTP). 
$(\mathrm{t}, 3 \mathrm{H}),-2.88(\mathrm{~s}, 2 \mathrm{H}, \mathrm{NH})$; ESI-MS: $m / z=859(100 \%$, $\left.(\mathrm{M}+\mathrm{H})^{+}\right) ; \mathrm{C}_{57} \mathrm{H}_{59} \mathrm{~N}_{7} \mathrm{O}_{1}$ : Calcd. C, 76.56; H, 7.10; N, 10.96. Found: C, 76.79; H, 6.76; N, 10.81\%.

Photofrin II was purchased from Axcan Pharma Company. For in vitro confocal microscopy studies it was dissolved in distilled water at a maximum concentration of $2 \mathrm{mg} / \mathrm{ml}$ and diluted using DMEM medium without phenol red. A pure sample of 5,10,15,20-tetraphenylporphyrin (TPP) was available from previous studies [15].

\subsection{Photophysical studies}

In the photophysical characterisation of the sensitisers toluene was used as a solvent. The results obtained should be indicative of sensitiser behaviour in cellular environment, although absolute values should be looked with caution as deviations may arise due to specific interactions. The ground-state absorption and luminescence spectra were recorded at room temperature with a Shimadzu UV-2100 spectrophotometer and SPEX Fluorolog 111 spectrophotometer, respectively. Transient triplet-triplet absorption was measured with an Applied Photophysics LKS.60 flash kinetic spectrometer; excitation was achieved with the third harmonic of a Nd/YAG laser (Spectra-Physics Quanta Ray GCR 130).

Singlet oxygen phosphorescence was detected at room temperature using an adaptation of the LKS.60 spectrometer. The singlet oxygen emission was detected using a Hamamatsu R5509-42 photomultiplier, cooled to $193 \mathrm{~K}$ in a liquid nitrogen chamber (Products for Research, model PC176TSCE005), following Nd/YAG laser excitation of aerated toluene solutions containing the sensitiser at a concentration necessary to produce absorbance in the 0.15 0.30 range at the excitation wavelength $(355 \mathrm{~nm})$. Under these conditions there was no indications of porphyrins' aggregation.

The modification of the spectrometer involved the interposition of a Melles Griot dielectric mirror (08MLQ005/ 345 ), that reflects more than $99.5 \%$ of the incident light in the $610-860 \mathrm{~nm}$ range and a Scotch RG665 filter. A 600 line diffraction grating was mounted in place of a standard one. This equipment allows spectral identification of the singlet oxygen phosphorescence and measurement of singlet oxygen lifetime in the nanosecond and microsecond ranges [16]. The filters employed are essential in eliminating from the infrared signal all first-harmonic contributions of the sensitiser emission in the $500-800 \mathrm{~nm}$ range.

\subsection{In vitro studies}

\subsubsection{Cell cultures}

Human malignant melanoma (Me45) cell line (derived from a lymph node metastasis of skin melanoma in a 35year-old male) was established in 1997 at the Radiobiology Department of the Centre of Oncology in Gliwice. Identity of melanoma cells was confirmed by immunocytochemical reaction with DAKO monoclonal antibodies HMB 50,
S-100 and Melan A (Widel, unpublished). Human colon adenocarcinoma (Hct116) was obtained from American Type Culture Collection. Murine melanoma (B16(F10)) was obtained from Wistar Institute, Philadelphia, PA, USA. Cells were grown as monolayer cultures in $75 \mathrm{~cm}^{2}$ flasks (Nunc) $/ 37^{\circ} \mathrm{C}$, humidified atmosphere, $5 \% \mathrm{CO}_{2} /$ using the following media: DMEM (Me45), McCoy (Hct116) and RPMI (B16(F10)) from Sigma-Aldrich, supplemented with $10 \%$ foetal bovine serum (Gibco-BRL) and $100 \mu \mathrm{g} / \mathrm{ml}$ of gentamycin (Polfa).

\subsubsection{Liposome preparation}

Liposomes used in this study contained a cationic component, cetylated polyethylenimine (CT-PEI), obtained by partially substituting amine groups of low-molecularweight polyetylenimine with cetyl residues. Synthesis of CT-PEI was performed according to Yamazaki et al. [17]. In brief, Epomin (low-molecular-weight polyethylenimine 600, Nippon Shokubai Ltd., Japan) was refluxed with cetyl bromide (Sigma-Aldrich) in the presence of triethylamine for $12 \mathrm{~h}$ at $63{ }^{\circ} \mathrm{C}$. The product was dialysed against $40 \%$ ethanol, then against water, and finally lyophilised.

The final product was ${ }^{1} \mathrm{H}$ NMR-analysed using Unity Inova-300 spectrometer operating at $300 \mathrm{MHz}$ frequency (Institute of Organic Chemistry and Technology, Silesian Technical University in Gliwice, Poland) with deuterated chloroform as solvent and tetramethylsilane as reference. The liposomes were prepared by mixing aliquots of chloroform solutions $(10 \mathrm{mg} / \mathrm{ml})$ of CT-PEI, cholesterol, and TPYR-PP or C16-TTP at appropriate molar ratios and spin-evaporating the resulting preparations. Dry lipid films were rehydrated at $4{ }^{\circ} \mathrm{C}$ for $1 \mathrm{~h}$ and sonicated with tip probe until emulsions became clear (two or three 3-min cycles, medium power, Branson sonifier).

\subsubsection{In vitro transfection studies}

Transfection studies with cationic liposome-plasmid DNA complexes (lipoplexes) at various stoichiometric ratios were performed in order to check cellular internalisation of constructs containing the synthesised compounds. Transfection calibration was achieved by employing complexes containing plasmid DNA (Promega) with luciferase reporter gene insert. The resulting luminescence of expressed luciferase protein was quantified using a Berthold luminometer. One day prior to transfection, cells were seeded onto 24 -well plates at $5 \times 10^{4}$ cells/well. When cultures reached about $80 \%$ confluence, appropriate dilutions of liposome emulsions were prepared in $100 \mu \mathrm{l}$ final volume using polystyrene tubes (Sarstedt). Separately, appropriate dilutions of $1 \mu \mathrm{g}$ plasmid DNA were prepared in polystyrene tubes in $100 \mu \mathrm{l}$ final volume. DNA solutions were added drop wise to liposomal emulsions with gently mixing. Following 15-min incubation at room temperature $2.8 \mathrm{ml}$ of suitable medium (Opti-MEM, Gibco-BRL) was added. After removal of growth medium the transfection mixtures were transferred to the culture wells. Cells were incubated for $4 \mathrm{~h}$ at $37^{\circ} \mathrm{C}$ and $5 \% \mathrm{CO}_{2}$. At the end of 
incubation period the transfection medium was replaced with regular growth medium. After $24 \mathrm{~h}$ cells in each well were lysed using a kit-included lysis buffer (Promega). The lysates were centrifuged for $30 \mathrm{~min}$ at $15,000 \mathrm{rpm}$ and $4{ }^{\circ} \mathrm{C}$. The supernatants $(300 \mu \mathrm{l})$ were transferred into fresh test tubes. Luciferase activity was determined using a Berthold luminometer, in supernatant aliquots $(20 \mu 1$ or less), after addition of $100 \mu \mathrm{l}$ of enzyme substrate. Luciferase activity was expressed as relative luminescence units (RLU) per milligram of protein in cell culture homogenates. Lysate protein content was measured by Bradford method using a BioRad kit and BSA calibration.

\subsubsection{Photostability studies of the compounds}

Photostability of the photosensitisers was determined by irradiating $1 \mu \mathrm{M}$ solutions of the phorphyrins incorporated into liposomes. Two different light doses were used (7.5 and $15 \mathrm{~J} / \mathrm{cm}^{2}$ ). During such irradiation the solutions were magnetically stirred and kept at room temperature. After appropriate time intervals concentration of the porphyrins was determined using absorption spectrophotometer. The photostability was calculated as the ratio of residual absorbance after determined irradiation time and the absorbance value measured before irradiation.

\subsubsection{Cytotoxicity and phototoxicity}

For irradiation experiments, exponentially growing cells were harvested by trypsinisation of subconfluent cultures. Cells were then seeded at $8 \times 10^{4}$ cells $/ 35 \mathrm{~mm}$ dish (Nunc). After $18 \mathrm{~h}$ incubation, the growth medium was exchanged for medium containing preselected (i.e., the best in terms of liposome stability and transfection efficiency) formulation of lipoplexes (6:1 lipid to DNA, w/w, final concentration of porphyrins $1 \mu \mathrm{M})$ and cells were incubated $4 \mathrm{~h}$ in the dark. A representative experiment calibrating liposome to DNA ratio is shown in Fig. 2, for details see Section 2.3.3. Prior to light exposure, cells were washed three times with phenol red-free medium (DMEM). The dishes were then exposed to different light doses $\left(2.5-15 \mathrm{~J} / \mathrm{cm}^{2}\right)$. First control group (no photosensitiser) was also treated with red light. The second control group, containing photosensitiser, was not exposed to light (dark control) and served for cytotoxicity assay. The light source was a halogen lamp $(250 \mathrm{~W}, 24 \mathrm{~V})$ with heat isolation filter and $610 \mathrm{~nm}$ longpass filter. The total power output (measured at the culture solution surface) was $8.5 \mathrm{~mW} / \mathrm{cm}^{2}$, as indicated by Radiometer Laser Mate-Q, Coherent. Immediately after irradiation the medium was replaced with fresh aliquot supplemented with $10 \%$ FBS and cells were further incubated for 12 or $24 \mathrm{~h}$ under standard culture conditions.

\subsubsection{Cell viability}

Cell viability was monitored by MTS-tetrazolium reduction assay (Promega) which relies on the ability of viable cells to reduce the colourless blue-tetrazolium salt (3-(4,5-dimethylthiazol-2-yl)-5-(3-carboxymethoxyphenyl)2-(4-sulfophenyl)-2H-tetrazol) to colour formazan. MTS, which measures mitochondrial dehydrogenase activity, was added to cell cultures 12 and $24 \mathrm{~h}$ after treatment with photosensitisers and/or light, according to the manufacturer's instructions. Absorbance measurements at $490 \mathrm{~nm}$ were performed using $\mathrm{El}_{\mathrm{x}} 800$ universal plate reader (Biotek Instruments, Inc.). A standard solution containing $100 \mu \mathrm{l}$ of DMEM without phenol red and $20 \mu \mathrm{l}$ of MTS solution was used to determine "blank" absorbance. Survival of PDT-treated cells was normalised against control cells that were only incubated (not irradiated). The results are reported as mean $\pm \mathrm{SD}$ of three separate experiments.

\subsubsection{Clonogenic survival assay}

Clonogenic potential of cells subjected to PDT treatment following transfer of C16-TTP and TPYR-PP containing constructs was assessed as described by

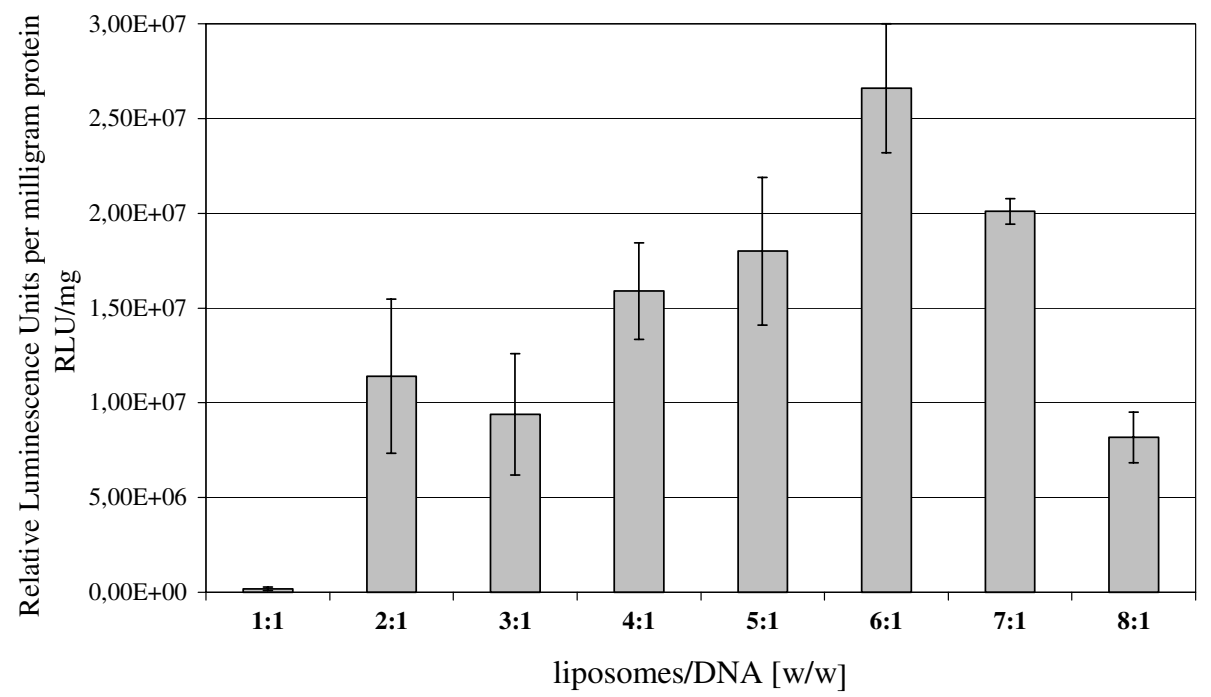

Fig. 2. Luciferase expression in Hct116 cells following transfection with plasmid DNA (pVR1255). Complexed to liposomes containing cetylated polyethylenimine CT-PEI, cholesterol $(1: 1 \mathrm{~mol} / \mathrm{mol})$ and C16-TTP. 
Carmichael [18]. Exponentially growing cells seeded in 35$\mathrm{mm}$ dishes (Nunc) were subjected to PDT, as described in Section 2.3.4. After irradiation with different light doses, cells were trypsinised and seeded, at different densities, in $60-\mathrm{mm}$ dishes. Cells were then incubated for 9 days at $37{ }^{\circ} \mathrm{C}$ in humidified atmosphere. The colonies were then fixed and stained with $0.5 \%$ methylene blue in $50 \%$ ethanol and the number of colonies containing more than 50 cells was counted. The surviving fraction was calculated as the relative plating efficiency of PDT-treated vs. non-PDTtreated cells (no drug, no light).

\subsubsection{Sensitiser localisation (confocal microscopy)}

To visualise the sensitisers accumulation within the cells, $3 \times 10^{4} \mathrm{Me} 45$ cells in $800 \mu \mathrm{l}$ growth medium were plated into 4-well chambered coverglass (Nunc) and incubated for $18 \mathrm{~h}$. Then, cells were transfected with liposome complexes containing C16-TTP or TPYR-PP (final concentration $1 \mu \mathrm{M}$ ), as described in Section 2.3.3. Following $4 \mathrm{~h}$ incubation cells were washed three times in phosphate-buffered saline (PBS, pH 7.2) and covered with $800 \mu$ of fresh growth medium. Thirty minutes before analysis cells were labelled with $5 \mu \mathrm{M}$ CellTracker Green CMFDA (5-chloromethylfluorescein diacetate; Molecular Probes). This reagent passes freely through cell membrane but, once inside the cell, its chloromethyl group reacts with thiols and the reagent is transformed into membrane-impermeant thioether adduct, fluorescing after esterases-mediated cleavage of acetate moiety. It allows localising targeted cells and assessing their viability. After 4 and $12 \mathrm{~h}$ incubation intracellular localisation of porphyrin derivatives was monitored using LSM 510 confocal laser scanning microscope (Carl Zeiss $\mathrm{GmbH})$. CellTracker Green CMFDA and porphyrins were excited using argon-ion laser $488 \mathrm{~nm}$ line and helium-neon laser $543 \mathrm{~nm}$ line, respectively. The fluorescence was filtered with $505 \mathrm{~nm}$ band-pass and $560 \mathrm{~nm}$ long-pass emission filters. To reduce interchannel cross-talk a multitracking technique was used. Image acquisition was performed using $40 \times 1.30 \mathrm{NA}$ oil immersion objective lens (resolution: $512 \times 512$ or $1024 \times 1024$ pixels; optical slice thickness: $1 \mu \mathrm{m}$ ). Images were stored in TIF format and analysed using KS400 software (Carl Zeiss $\mathrm{GmbH})$. Five images were taken for each kind of lipoplex-associated porphyrins and controls cell cultures (without lipoplexes added). Every image featured 5-7 cells. Using green image channel the mask for definition of ROI was generated. In such defined regions mean densitometric signal value was calculated after background fluorescence subtraction.

To determine exact intracellular localisation of drugs 3D reconstructions of specified cells were generated. Our source image stacks consisted of 55 (two-channel, $1024 \times$ 1024 pixels) images taken every $0.4 \mu \mathrm{m}$. Final resolution of this reconstruction was $0.16 \mu \mathrm{m} /$ pixel horizontally and $0.4 \mu \mathrm{m} /$ pixel vertically. Acquisition time was $1.17 \mathrm{~s}$ per image ( $65 \mathrm{~s}$ for entire stack). Using these stacks horizontal and vertical projections were generated.

\subsubsection{Determination of apoptotic cells}

To study the mode of cell death following PDT we used differential staining of apoptotic and necrotic cells with acridine orange/ethidium bromide (AO/EB) [19,20]. Tumour cells (Me45) growing on $35 \mathrm{~mm}$ culture dishes were transfected with porphyrin-carrying liposomes for $4 \mathrm{~h}$ as described in Section 2.3.3 and irradiated with two different light energy doses: 7.5 and $15 \mathrm{~J} / \mathrm{cm}^{2}$. Next, cells were washed with fresh medium and incubated $0-24 \mathrm{~h}$. At times $0,3,6,12$ and $24 \mathrm{~h}$ cells were trypsinised, pelleted, suspended in $25 \mu$ of phosphate buffered saline (PBS) and $1 \mu \mathrm{l}$ of AO/EB $(1: 1,10 \mu \mathrm{M})$ solution was added. A drop of cell suspension was placed on microscope slide and analysed at $400 \times$ magnification under fluorescence microscope (AXIOPHOT, Zeiss-Opton) equipped with band-pass filter for $400-500 \mathrm{~nm}$ wavelength. One thousand cells were scored and percentage of live, apoptotic and necrotic cells was calculated. Live cells contain green fluorescent regular nuclei with orange granules in the cytoplasm; apoptotic cells present nuclei with intense green fluorescence from condensed chromatin (early apoptosis) and bright orange fluorescence from highly condensed and/or fragmented chromatin (late apoptosis); necrotic cells possess regular orange-stained nuclei and often disrupted cell membrane which is clearly seen using phase-contrast objective [20].

\section{Results}

\subsection{Photophysics and photochemistry}

C16-TTP and TPYR-PP show typical spectroscopic features of free-base porphyrins (intense Soret band) in the violet range of the visible region $\left(\varepsilon>10^{5} \mathrm{M}^{-1} \mathrm{~cm}^{-1}\right)$ and four wide Q-bands localised in the $500-650 \mathrm{~nm}$ region $\left(\varepsilon \leqslant 10^{4} \mathrm{M}^{-1} \mathrm{~cm}^{-1}\right)$; the data are summarised in Table 1 . The band absorption coefficient was calculated from Lambert-Beer law using solutions in the $10^{-4}-10^{-6} \mathrm{M}$ concentration range. The relative intensity of the Q-bands indicates an etio-type spectrum $\left(\varepsilon_{\mathrm{IV}}>\varepsilon_{\mathrm{III}}>\varepsilon_{\mathrm{II}}>\varepsilon_{\mathrm{II}}\right)$, [21]. Good linear plots $(r \geqslant 0.999)$ that pass through the origin were obtained, indicating that there is no compound aggregation under these conditions. However, this does not exclude the possibility of aggregation inside cells in vitro, which is often the case for this kind of compounds.

The steady-state fluorescence emission spectra of these porphyrins present two maxima which have been assigned to $\mathrm{Q}(0-0)$ and $\mathrm{Q}(0-1)$ transitions, see Table 1 . A very small $(5 \mathrm{~nm})$ Stokes shift between last band of absorption $\mathrm{Q}_{x}(0-0)$ and first emission band $\mathrm{Q}(0-0)$, characteristic for monomeric porphyrins, was also observed indicating that the spectroscopic energy is nearly identical to the relaxation energy of the singlet state. The fluorescence quantum yield $\left(\Phi_{\mathrm{F}}\right)$ was calculated by steady-state comparative method using TPP as reference. The spectroscopic singlet-state energies $\left(E_{\mathrm{S}}\right)$ were obtained from the intersection of the normalised absorption and fluorescence spectra. No phosphorescence was observed at $77 \mathrm{~K}$ in toluene glasses. 
Table 1

Absorption and luminescence data for free bases in deaerated toluene solution

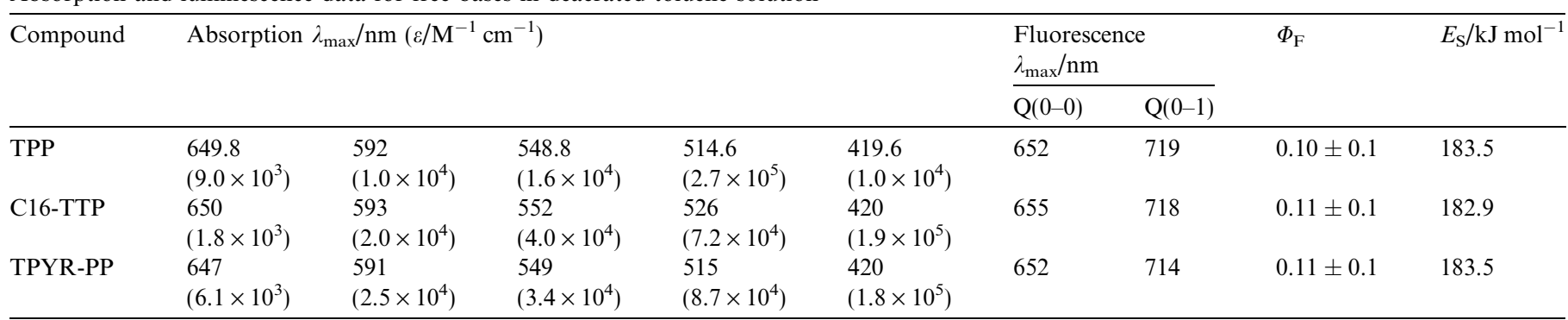

All results are consistent with those obtained for TPP and related porphyrins $[15,22,23]$.

Triplet-triplet absorption spectra of both porphyrins presented typical intense absorption band at $\approx 460 \mathrm{~nm}$ and the ground state bleaching bands. Triplet state lifetimes in presence (air-equilibrated samples) and absence of oxygen were obtained. Triplet quantum yields $\left(\Phi_{\mathrm{T}}\right)$ were calculated using a published procedure [24] (see Table 2).

\subsection{Quantum yield of singlet oxygen generation}

Singlet oxygen quantum yields $\left(\Phi_{\Delta}\right)$ were obtained by comparing the intensity of singlet oxygen emission at $1270 \mathrm{~nm}$ in an air-equilibrated sample containing a given sensitiser against the intensity obtained from an optically matched sample containing a reference sensitiser. The laser power employed was varied until reaching the lowest emission signal limit (Fig. 3). We employed $1 \mathrm{H}$-phenalen-1-one as a reference. The literature value for the singlet oxygen quantum yield in toluene, obtained for this sensitiser is $0.95[25]$.

The studied molecules generate a species emitting at $1270 \mathrm{~nm}$ with the lifetime between 32 and $35 \mu$ s (Table 2). These values are in good agreement with lifetime of singlet oxygen phosphorescence in the solvent used, confirming the origin of the emission measured [26]. Also, the shape of emission spectra taken between 1200 and $1350 \mathrm{~nm}$ corresponds to that emission, with a maximum at $1270 \mathrm{~nm}$ [27].

The oxygen quantum yield values obtained for TPP and Photofrin II (0.62 and 0.32, respectively) are in full agreement with those found in the literature [28,29], which validates the method used. The value of 0.32 obtained for the complex mixture Photofrin II in toluene is within the range of the values obtained for pure hematoporphyrins in this solvent [30]. C16-TTP has a singlet oxygen quantum yield (0.66) comparable to that of TPP, twice the value for Photofrin II under the same measuring conditions. TPYR-PP yield of singlet oxygen generation reaches the value of 0.82 which is quite enhanced, compared to those for Photofrin II or even C16-TPP and TPP (Table 2). The value obtained for TPYR-PP can be compared with the value obtained by Postigo et al. [31] for tetra-pyridylporphyrin in the same solvent $(0.85)$.

\subsection{Photostability of compounds}

In all cases, exposure of liposome-incorporated porphyrins to light doses used in phototoxicity studies caused a negligible decrease in the intensity of the visible absorption bands. This process, generally defined as photobleaching, is usually related to irreversible destruction of the tetrapyrrolic macrocycle. The data in Table 3 evidently suggest that TPYR-PP and C16-TTP have shown high photostability under the conditions used for PDT tests.

\subsection{PDT effects on the cell growth and survival}

The purpose of this group of experiments was to determine the degree of dark toxicity and phototoxicity of C16TTP and TPYR-PP for various transfected cell lines following exposure to different doses of light. The use of cationic liposomes as photosensitiser vehicles transporting hydrophobic constitutes an advantage for their use in PDT, since liposomes optimise the release of lipophilic sensitisers to low density lipoproteins LDL. The percentage of cell survival was measured by normalising the results of MTS assay with cells that were neither exposed to porphyrins nor to light.

Table 2

Triplet state characterisation, singlet oxygen lifetimes and quantum yields

\begin{tabular}{llllll}
\hline Compound & Triplet lifetime $\left(\mathrm{N}_{2}\right) / \mu \mathrm{s}$ & Triplet lifetime $(\mathrm{air}) / \mathrm{ns}$ & $\Phi_{\mathrm{T}}$ & ${ }^{1} \mathrm{O}_{2}$ emission lifetime/ $/ \mu \mathrm{s}$ & ${ }^{1} \mathrm{O}_{2}$ quantum yield \\
\hline 1H-phenalen-1-one & - & - & - & $32.0 \pm 0.8$ & 0.95 \\
TPP & $>10^{\mathrm{a}}$ & $196^{\mathrm{a}}$ & $0.73^{\mathrm{a}} / 0.67^{\mathrm{b}}$ & $32.9 \pm 1.2$ & 0.62 \\
Photofrin II & - & - & - & $33.0 \pm 1.9$ & 0.32 \\
C16-TTP & 64 & 338 & 0.63 & $31.1 \pm 0.9$ & 0.66 \\
TPYR-PP & 43 & 315 & 0.81 & $31.0 \pm 2.5$ & 0.82 \\
\hline
\end{tabular}

\footnotetext{
${ }^{\mathrm{a}}$ Ref. [15].

${ }^{b}$ Ref. [30].
} 

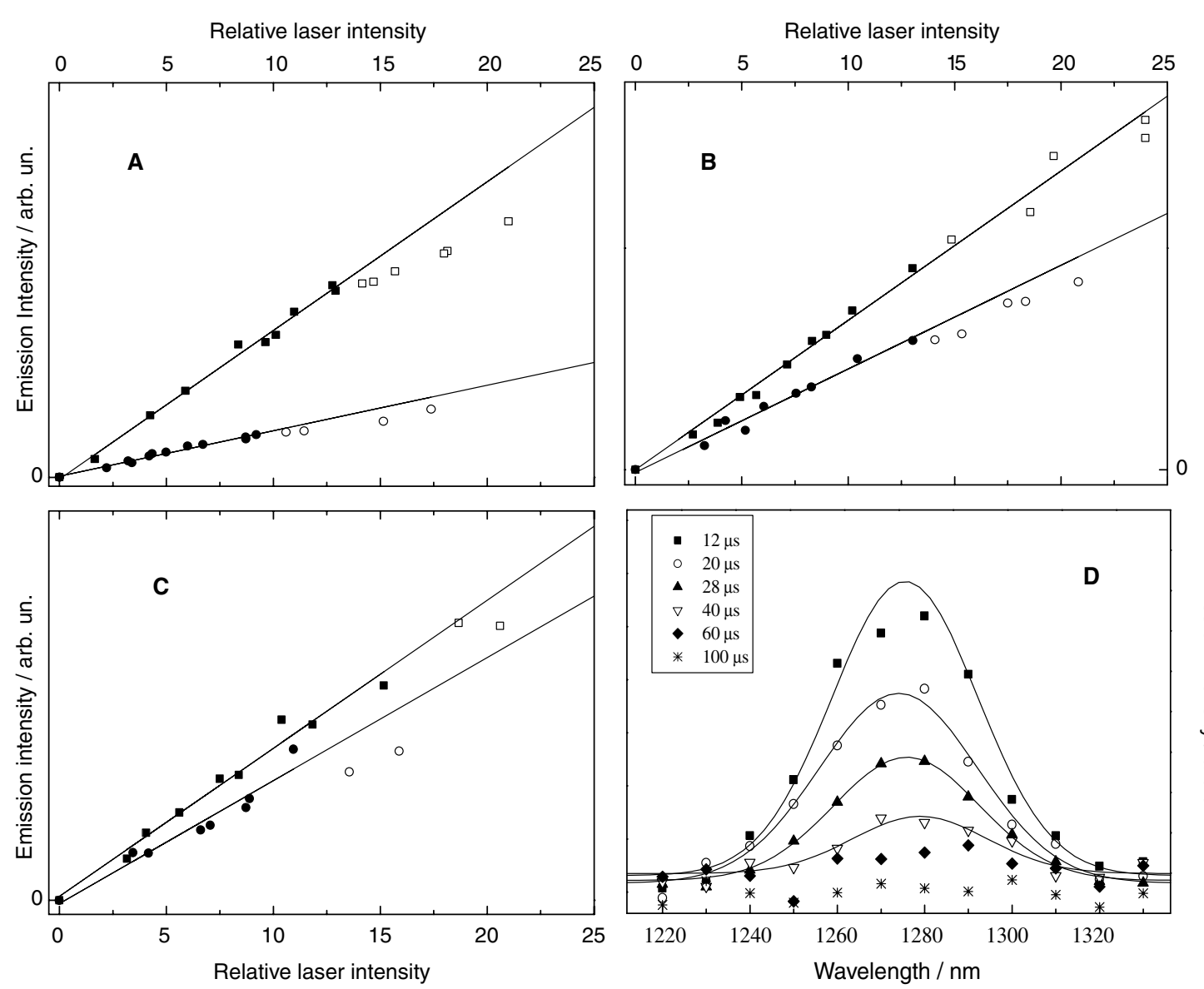

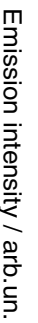

Fig. 3. $1270 \mathrm{~nm}$ emission intensity as a function of relative laser intensity: (squares) $1 H$-phenalen-1-one; (circles) A, Photofrin II; B, C16-TPP; C, TPYRPP; D, emission intensity as a function of wavelength for C16-TPP.

Table 3

Photostability percentage of the photosensitisers after irradiation with different light doses

\begin{tabular}{llll}
\hline Compound & \multicolumn{2}{l}{ Energy dose $/ \mathrm{J} \mathrm{cm}^{-2}$} & \\
\cline { 2 - 4 } & 0 & 7.5 & 15 \\
\hline C16-TTP & 100 & 99 & 98 \\
TPYR-PP & 100 & 98 & 94 \\
\hline
\end{tabular}

Figs. 4 and 5 show the characteristics of C16-TTP and TPYR-PP phototoxicity after exposure to five doses of light irradiation, respectively. Cell viability was measured $12 \mathrm{~h} \mathrm{(A)} \mathrm{and} 24 \mathrm{~h}$ (B) post-irradiation in three different cell lines. When the cells were exposed to light in the absence of the compounds no toxicity was recorded (data not presented). Only negligible proliferative change was observed when the treatment with drug was conducted in the absence of light ( 0 energy dose in Figs. 4 and 5). This proves that neither light nor photosensitiser are toxic separately. When incubating cells with studied agents and irradiating them with various energy doses cells demonstrated inhibited proliferation compared to control. As expected, cell survival was dependent on the dose of energy used and was significantly decreased when the dose was raised. The survival effect was also proportional to the time period elapsed from conclusion of light exposure. Comparing the effectiveness of the studied compounds TPYR-PP derivative turned out to be more efficient than C16-TTP, demonstrating results after $24 \mathrm{~h}$ from light irradiation.

Human melanoma (Me45) appears to be the most resistant cell line. In contrast, human colon adenocarcinoma (Hct116) shows greatest sensitivity to irradiation after $24 \mathrm{~h}$ post-light exposure. We have also calculated the $\mathrm{LD}_{50}$, i.e., the light dose, required for killing $50 \%$ of the cells at a given drug concentration (Figs. 4 and 5). For Hct116 line cells treated with C16-TTP after 12 and $24 \mathrm{~h}$ from the conclusion of light exposure the required energy dose to observe this effect was 5 and $3 \mathrm{~J} / \mathrm{cm}^{2}$, respectively. $\mathrm{LD}_{50}$ figured out for Me45 cell line after $12 \mathrm{~h}$ was $12.5 \mathrm{~J} / \mathrm{cm}^{2}$ and after $24 \mathrm{~h}$ it was $7.5 \mathrm{~J} / \mathrm{cm}^{2}$. The most resistant to C16-TTP-mediated PDT treatment was B16(F10) melanoma which required $15 \mathrm{~J} / \mathrm{cm}^{2}$ after $12 \mathrm{~h}$ and nearly $10 \mathrm{~J} / \mathrm{cm}^{2}$ after $24 \mathrm{~h}$, respectively. In case of using TPYRPP the energy dose leading to $50 \% \mathrm{~B} 16(\mathrm{~F} 10)$ cell death was $7.5 \mathrm{~J} / \mathrm{cm}^{2}$ after $12 \mathrm{~h}$. For the two remaining cell lines the dose was nearly twice higher. After $24 \mathrm{~h}$ the $\mathrm{LD}_{50}$ dose was similar for all cell lines studied, ca. $6-7.5 \mathrm{~J} / \mathrm{cm}^{2}$. At a light dose of $15 \mathrm{~J} / \mathrm{cm}^{2}$ after $24 \mathrm{~h}$ from using TPYR-PP the survival of Hct 116 cells was less than $10 \%$. These results indicate that both compounds show PDT effect. 

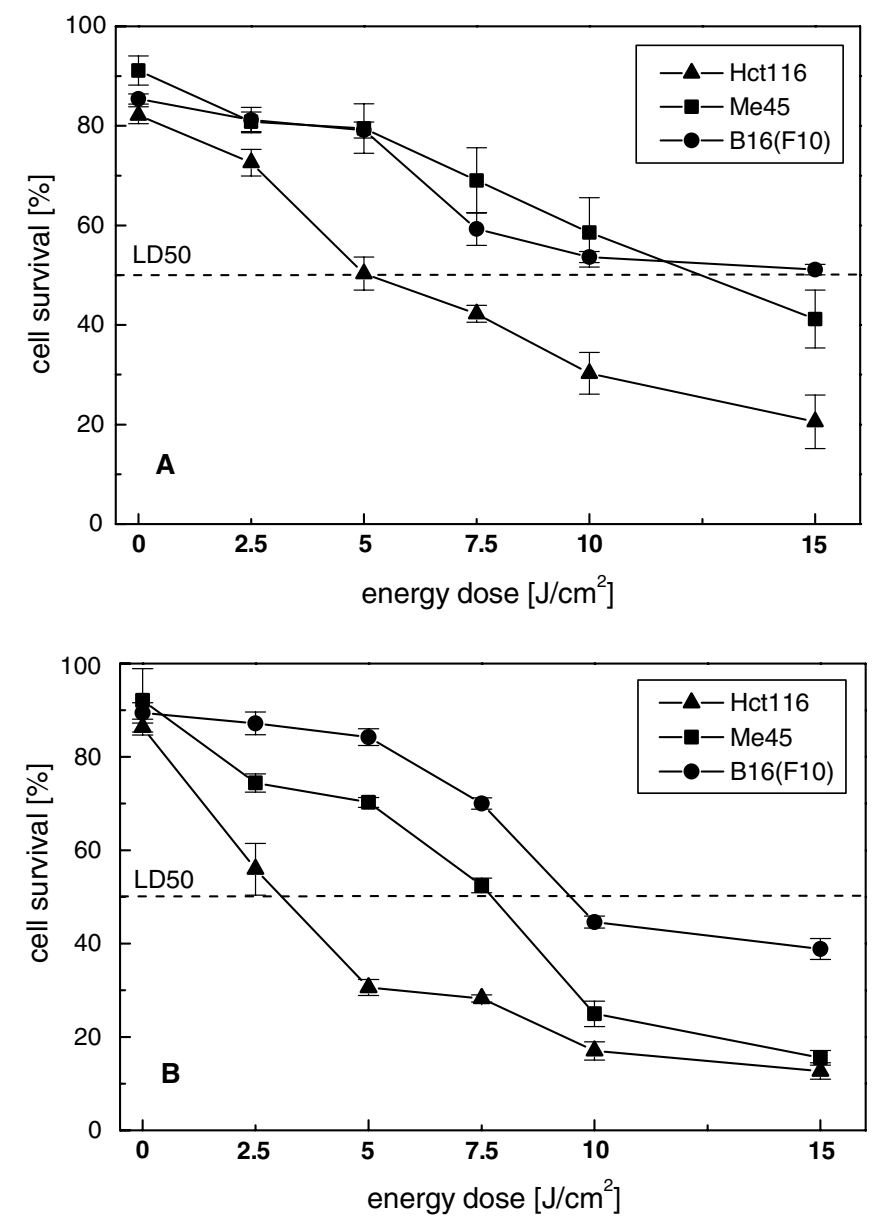

Fig. 4. Cytotoxicity of C16-TTP determined by MTS colorimetric assay at $12 \mathrm{~h} \mathrm{(A)}$ and $24 \mathrm{~h} \mathrm{(B)}$ after PDT treatment. Three cell lines were exposed to different light doses $\left(2.5-15 \mathrm{~J} / \mathrm{cm}^{2}\right)$. Data are expressed as mean $\pm \mathrm{SD}$ from at least three independent experiments.

\subsection{Clonogenic survival assay}

MTS test was used to generally characterise the antiproliferative effect of the tested compounds following light irradiation of cell cultures. This test does not allow to state unequivocally if the observed proliferation inhibition is reversible or not since it only gives information about the behaviour of certain metabolic functions (mitochondrial activity). The final result is additionally influenced by the rate of cellular divisions and by the rate of cell death. This is why, in order to confirm the results obtained using MTS test, also clonogenic assays were performed using chosen cell lines (Hct116 and Me45) and varying doses of light energy.

The results in Figs. 6 and 7 were obtained by comparison with the colony survival of untreated cells $(100 \%)$. They are in agreement with MTS data. As can be seen, light alone at doses $5-15 \mathrm{~J} / \mathrm{cm}^{2}$ was non-toxic for either cell line. The application of $1 \mu \mathrm{M}$ of porphyrin derivatives without irradiation slightly diminished the surviving fractions $(\mathrm{SF}=85-97 \%)$ of cells, indicating relatively low dark toxicity. In both cell lines the photodynamic effect
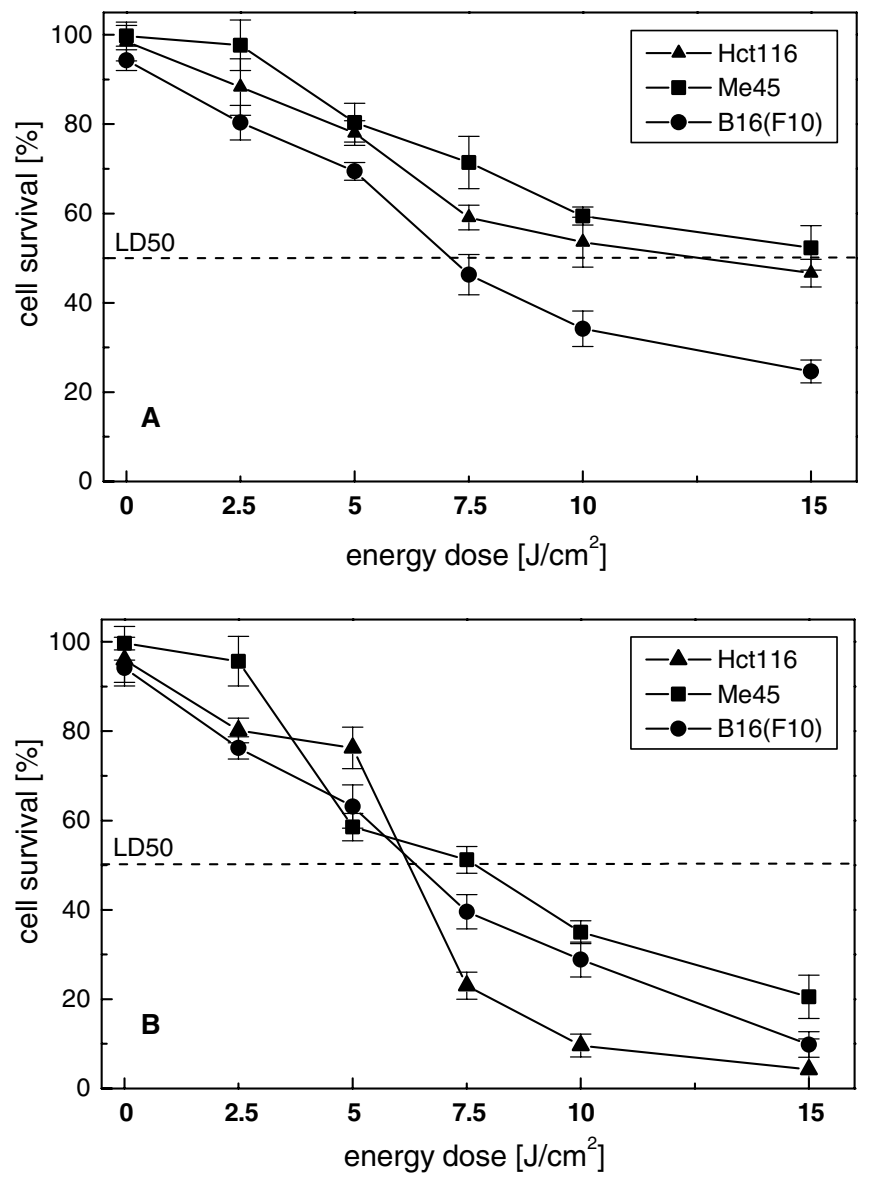

Fig. 5. Cytotoxicity of TPYR-PP determined by MTS colorimetric assay at $12 \mathrm{~h}(\mathrm{~A})$ and $24 \mathrm{~h}(\mathrm{~B})$ after PDT treatment. Three cell lines were exposed to different light doses $\left(2.5-15 \mathrm{~J} / \mathrm{cm}^{2}\right)$. Data are expressed as mean $\pm \mathrm{SD}$ from at least three independent experiments.

increased with light energy applied. However, after exposure of both cell lines to combined effect of sensitiser and light, higher efficiency of TPYR-PP, compared to

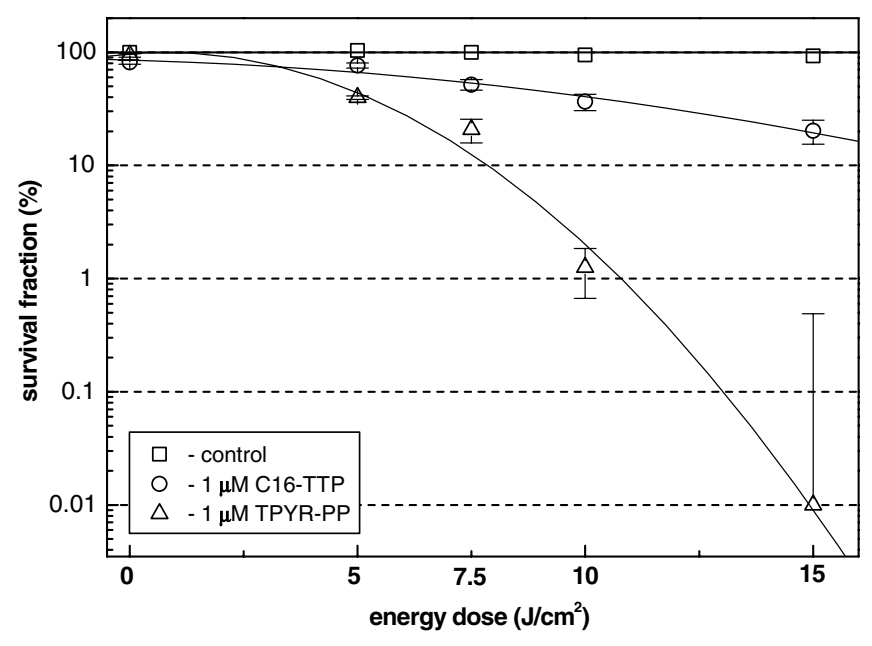

Fig. 6. Cell survival measured by clonogenic assay for Hct116 cells following PDT treatment with C16-TTP and TPYR-PP. After treatment cells were grown for additional 9 days in culture medium. Cell survival was expressed as a ratio of plating efficiency of treated cells to that of untreated cells. Each experiments were performed tree times (mean $\pm \mathrm{SD}$ ). 


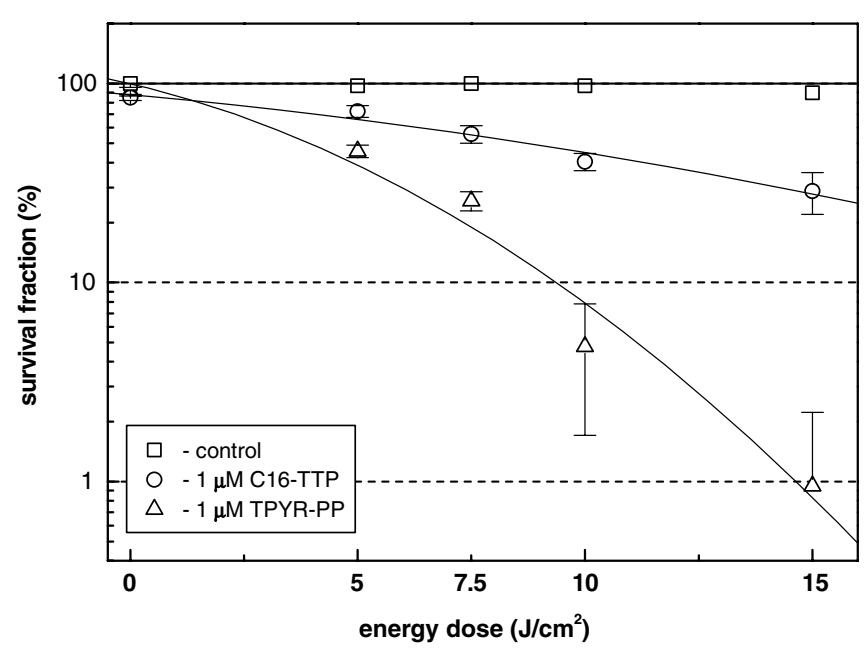

Fig. 7. Cell survival measured by clonogenic assay for Me45 cells following PDT treatment with C16-TTP and TPYR-PP. After treatment cells were grown for additional 9 days in culture medium. Cell survival was expressed as a ratio of plating efficiency of treated cells to that of untreated cells. Each experiments were performed tree times (mean $\pm \mathrm{SD}$ ).

C16-TTP, was clearly seen. Furthermore, it was observed that human colon adenocarcinoma cells were more sensitive to PDT treatment (especially with pyridyl-porphyrin derivative, TPYR-PP), than malignant melanoma cells. The surviving fraction of Hct116 cells after $15 \mathrm{~J} / \mathrm{cm}^{2}$ dose (Fig. 6) was two order of magnitude lower than that of malignant melanoma Me45 cells (Fig. 7).

\subsection{Intracellular localisation of C16-TTP and TPYR-PP in Me45 cells}

For PDT to be effective, the localisation of photosensitiser inside the cell is of substantial importance. It determines the mechanisms set in motion in the wake of photodynamic reactions. The manner according to which sensitisers are taken up by cells is related to their chemical nature and so is their localisation in intracellular microenvironment. This is why intracellular localisation of the studied porphyrin derivatives was analysed using confocal microscopy. The experiments were carried out using human melanoma cells Me45 which appeared relatively refractory to PDT therapy with the studied compounds.

The photosensitiser localisation was assessed after 4 and $12 \mathrm{~h}$ following conclusion of transfection. In both cases it appeared similar. After $4 \mathrm{~h}$ accumulation was stronger in the plasma membrane and in peripheral regions of the cytoplasm (Fig. 8B). In no case fluorescence was nucleuslocalised. After $12 \mathrm{~h}$ condensation of both derivatives was seen mainly in organelles around cell nucleus (Fig. 8C and $\mathrm{D}$ ). More precise determination of their localisation requires further studies involving specific organelle markers. For comparative purposes also intracellular localisation of Photofrin II $(5 \mu \mathrm{g} / \mathrm{ml})$ was checked after $12 \mathrm{~h}$ incubation. In this case intensive fluorescence diffused throughout the cytoplasm was seen (Fig. 8E). Using image analysis software fluorescence intensity was also deter- mined by computing mean optical density corresponding to horizontal projections of the cells treated with compounds and control. The results are shown in Table 4. As expected, the fluorescence intensity of TPYR-PP in cells was far greater than that of C16-TTP. The ratio of optical density measured in cells treated with TPYR-PP (after subtracting the background) to the optical density of cells exposed to C16-TTP is 1.6. TPYR-PP turned out to be a more effective PDT photosensitiser in studied cell lines.

\subsection{Determination of apoptotic cells}

Cell death is induced via two mechanisms: apoptosis or necrosis. Apoptosis is characterised by changes in cellular morphology, such as shrinkage, cell surface blebbing, chromatin condensation and DNA fragmentation. This type of morphology is different from the well-known necrotic type, characterised by swelling organelles, clumping of chromatin, breakdown of plasma membrane and, finally, total cell disintegration [32].

In our study PDT-treated and untreated controls were stained with AO/EB in order to verify the modes of cell death based on their morphological changes. The investigations were carried out on Hct116 cell line which showed to be the most sensitive to PDT. Two energy doses were used: 7.5 and $15 \mathrm{~J} / \mathrm{cm}^{2}$. Analysis was done right after irradiation and after 3, 6, 12, and $24 \mathrm{~h}$. One thousand cells were evaluated under fluorescent microscope (objective 40×), simultaneously using phase contrast. Percentage of undamaged cells, those in apoptosis and necrosis and cells undergoing mitosis were calculated.

Fig. 9A-D shows the results for C16-TTP derivative. Treatment of Hct116 cells only with light doses 7.5 and $15 \mathrm{~J} / \mathrm{cm}^{2}$ is almost non-toxic $(90-95 \%$ live cells, and very few apoptotic and necrotic cells). Differentiation of Hct116 cell response treated with C16-TTP is clearly dependent on energy dose used. Cells quickly undergo apoptosis, which is expected after PDT. Even shortly after irradiation $(0-3 \mathrm{~h}$, Fig. 9A-B) the percentage of apoptotic cells was ca. $25-37 \%$ for both low and high energy dose. For the higher dose after $3 \mathrm{~h}$ there were $14 \%$ of necrotic cells. After longer time periods the percentage of necrotic cells significantly increased for cultures treated with this energy dose, reaching $70 \%$ after $24 \mathrm{~h}$ (Fig. 9D). In the case of cells irradiated with $7.5 \mathrm{~J} / \mathrm{cm}^{2}$ dose after $3 \mathrm{~h}$ there was only a minor percentage of necrotic cells. At further time points their number slowly raised reaching ca. 35\% after $24 \mathrm{~h}$ (Fig. 9D). Apoptotic cells in this group show initial rise, but the percentage decreases with time, resulting in the microscopic picture being finally dominated by necrotic cells.

The results obtained for TPYR-PP (Fig. 10A-D) markedly differ from the results obtained for C16-TTP, although here one can notice as well differentiation of cellular response depending on light energy dose used. In this case, however, cells treated with both lower and higher energy doses exhibited a substantially lower percentage of 

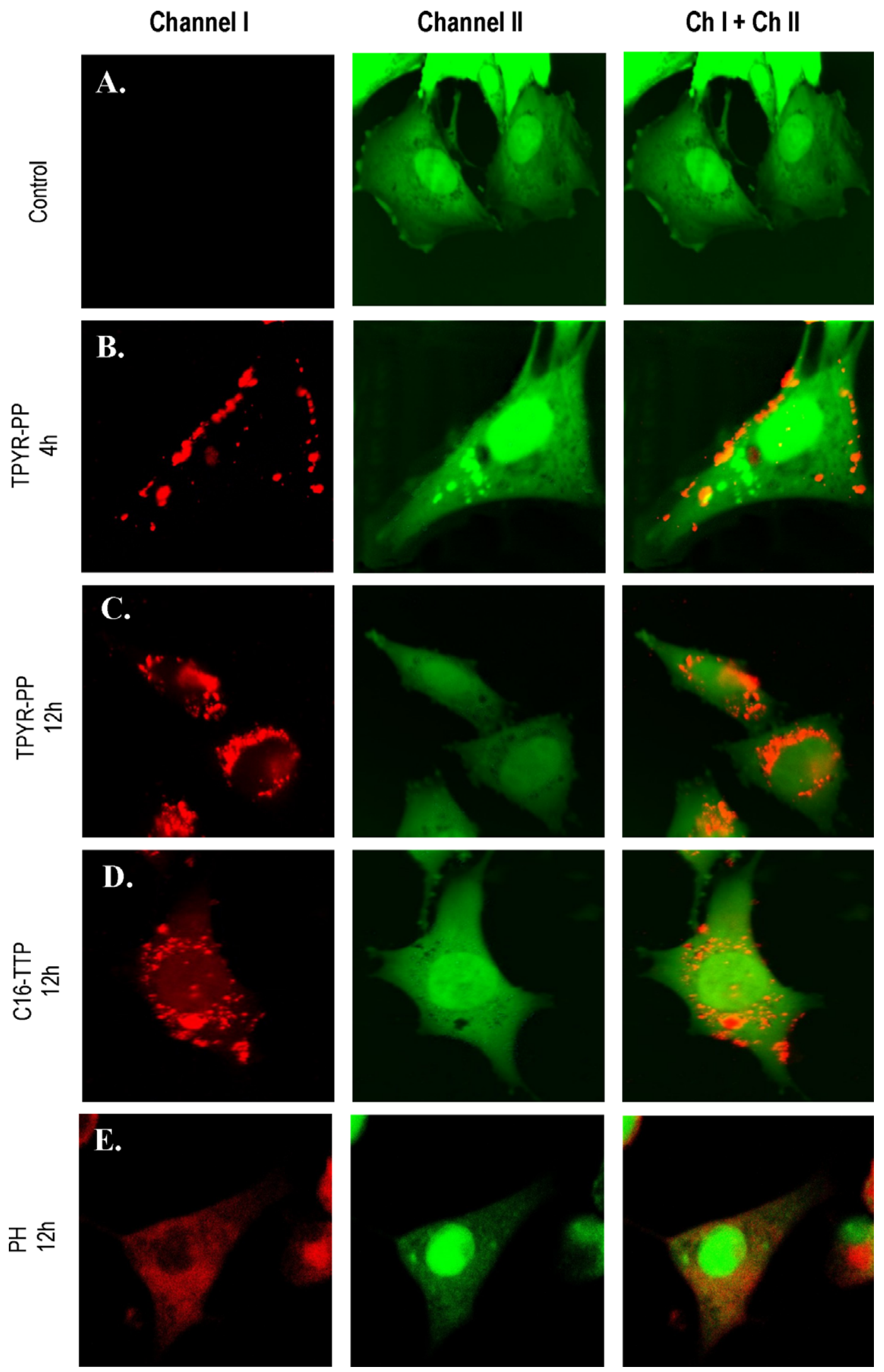

Fig. 8. Intracellular distribution of TPYR-PP, C16-TTP and PH in Me45 cells evaluated by confocal microscopy. 5-Chloromethylfluorescein diacetate (CMFDA) was used as a marker molecule. Porphyrins were excited by argon ion laser at $488 \mathrm{~nm}$ (red fluorescence image, channel I) and CMFDA by neon laser at $543 \mathrm{~nm}$ (green fluorescence image, channel II); combined multitruck system image (Ch I + Ch II) presents both type of fluorescence. 
Table 4

Intensity of the fluorescence from intracellular accumulation of C16-TTP and TPYR-PP

\begin{tabular}{lll}
\hline Group & Cells & Background \\
\cline { 2 - 3 } & Optical density (d.u. $\left.{ }^{\mathrm{a}}\right)$ & Optical density $\left(\right.$ d.u. $\left.{ }^{\mathrm{a}}\right)$ \\
\hline Control & 0.00 & 0.00 \\
TPYR-PP & 43.40 & 6.27 \\
C16-TTP & 24.95 & 2.03 \\
\hline
\end{tabular}

Ten images were taken for each kind of lipoplex-entrapped porphyrins and control cells. Every image features 5-7 cells. Mean densitometric value was calculated after background fluorescence subtraction.

a d.u., density units.

apoptotic cells. $3 \mathrm{~h}$ after conclusion of irradiation only 10 $15 \%$ cells showed features typical of apoptotic death. Thus, it seems that TPYR-PP use leads to necrosis as a dominant mode of death. For higher energy dose, just after irradiation, ca. $18 \%$ of cells were necrotic and the observed effect markedly increased with time. After $12 \mathrm{~h}$ the necrotic cells in the group irradiated with $15 \mathrm{~J} / \mathrm{cm}^{2}$ dose reached $37 \%$. After $24 \mathrm{~h}$ in the group treated with the same dose there was only $8 \%$ of live cells and more than $70 \%$ of cells were necrotic (Fig. 10D).

\section{Discussion}

Novel compounds that exhibit better therapeutic efficacy, lesser toxicity and which could be obtained at a lower costs, compared to presently used sensitisers, have been for many years the topic of extensive research. The effectiveness of photodynamic therapy strongly depends upon photochemical properties of photosensitisers and, in particular, upon the yield of singlet oxygen generation [33]. Both compounds studied TPYR-PP and C16-TTP are characterised by relatively high efficiency of singlet oxygen generation that is comparable or higher than that shown by current photosensitisers used in in vivo applications [34,35].

In view of the combined errors of the photophysical experiments, there is no statistically significant difference between the values obtained for the triplet and for the singlet-oxygen quantum yields of C16-TPP and TPYR-PP (see Table 2). The profile of the singlet oxygen decay curve is consistent with a fast formation from the quenched triplet state of the porphyrin $\left(\tau_{\mathrm{T}}(\mathrm{air}) \approx 300 \mathrm{~ns}\right)$. Triplet-triplet energy transfer from the sensitiser to oxygen ground-state occurs with unit efficiency upon collision, forming the $\mathrm{O}_{2}$ $\left({ }^{1} \Delta_{\mathrm{g}}\right)$ :

$$
\text { Porph }\left(\mathrm{T}_{1}\right)+{ }^{3} \mathrm{O}_{2} \rightarrow \operatorname{Porph}\left(\mathrm{S}_{0}\right)+{ }^{1} \mathrm{O}_{2}
$$

The rate of this reaction should approach the limit of oneninth of the diffusion-controlled constant [15]. Taking $\left[\mathrm{O}_{2}\right]=1.81 \times 10^{-3} \mathrm{M}$ for toluene at room temperature, Eq. (1) gives $k_{\mathrm{q}}=2 \times 10^{9} \mathrm{M}^{-1} \mathrm{~s}^{-1}$ for both compounds, which is very close to the theoretical limit of $\frac{1}{9} k_{\text {diff }}=$ $3.4 \times 10^{9} \mathrm{M}^{-1} \mathrm{~s}^{-1}$.

$\mathrm{k}_{\mathrm{q}}=\left(1 / \tau \mathrm{air}-1 / \tau \mathrm{N}_{2}\right) /\left[\mathrm{O}_{2}\right]$
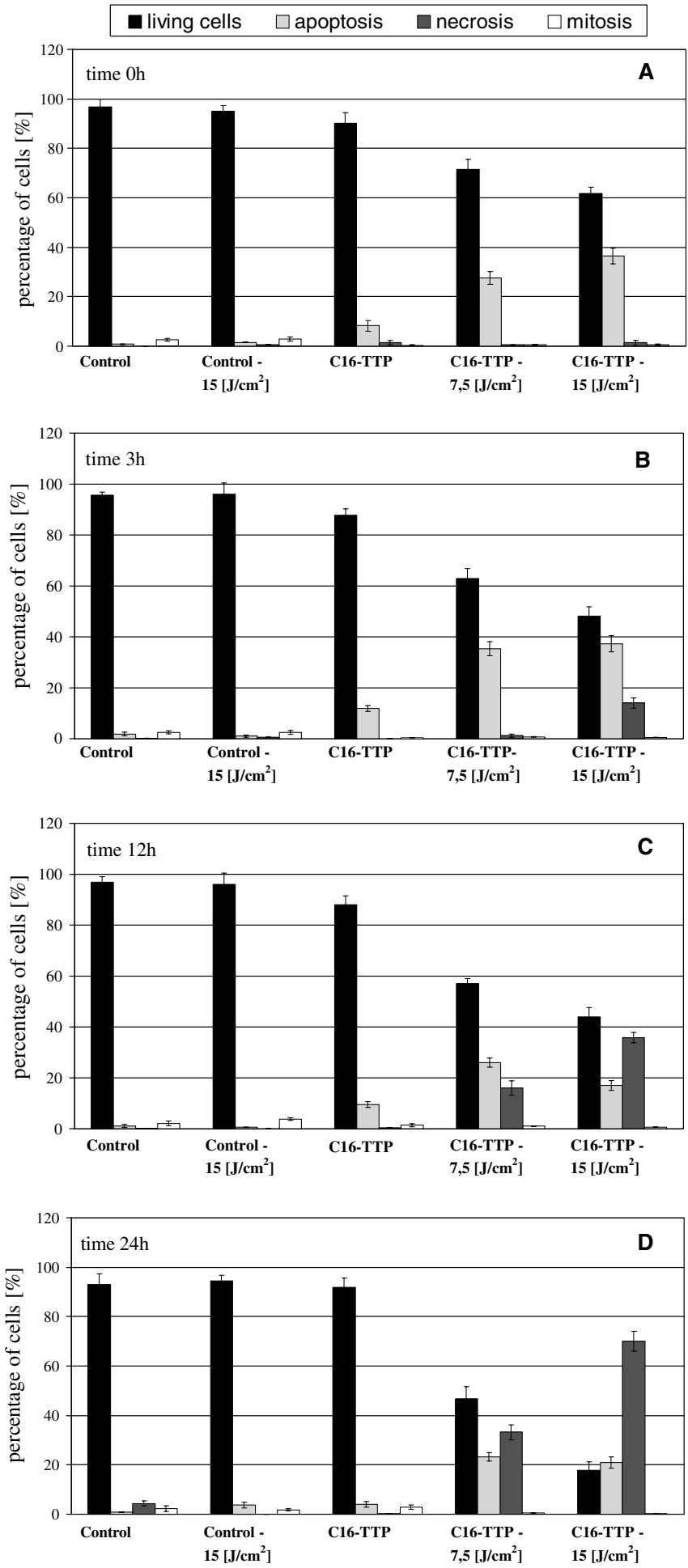

Fig. 9. Distribution of Hct116 cells (live, mitotic, apoptotic or necrotic) after PDT treatment with C16-TTP in function of light energy applied and post-treatment time elapsed.

The enhanced triplet quantum yield of TPYR-PP in tentatively assigned to an increase in the intersystems crossing rate of this sensitiser, and this can be originated by the nature of the pyridyl group. Groups with electrons in non-bonded orbitals tend to favour the conversion between singlet and triplet states. 

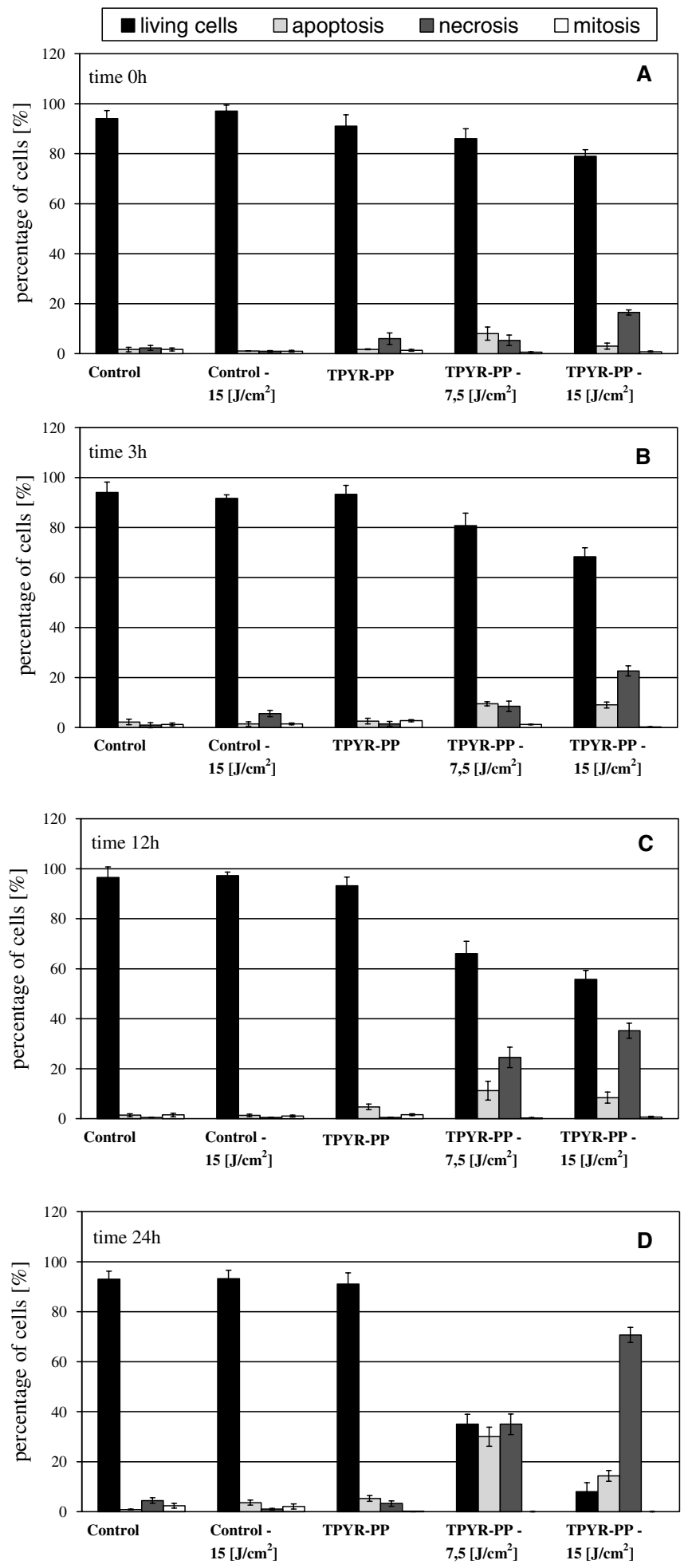

Fig. 10. Distribution of Hct116 cells (live, mitotic, apoptotic or necrotic) after PDT treatment with TPYR-PP in function of light energy applied and post-treatment time elapsed.

We also carried out biological studies in vitro of the two novel porphyrin derivatives, C16-TTP and TPYR-PP. For our study we chose three neoplastic cell lines showing variable resistance to PDT treatment: Me45 human melanoma, B16(F10) murine melanoma and Hct116 human colon adenocarcinoma. According to literature data, melanotic cells are thought to be particularly resistant to PDT, contrarily to carcinoma [36].

In recent years a progressive increase in melanoma morbidity throughout the world has been recorded among people of Caucasian ancestry. Melanoma is a very invasive kind of neoplasm with a tendency of rapid metastatic spread. This is why there is a lot of scepticism concerning PDT application for these tumours, all the more because presence of melanin, absorbing in the $500 \mathrm{~nm}$ region, may additionally hamper the effectiveness of PDT. Melanin may act as a free radical scavenger although the extent of such effect is limited [37]. In any case, it has to be remembered that skin is one of the most accessible targets for PDT which raises hope that this method some day might compete with respect to more traditional treatments and makes search for a photosensitiser effective against melanoma cells justified. Studies of ATX-S10(Na) have shown that this chlorine-type photosensitiser at $50 \mu \mathrm{g} / \mathrm{ml}$ caused $99 \%$ death of melanoma cells irradiated with $10 \mathrm{~J} / \mathrm{cm}^{2}$ [33]. Equally promising are the results of using indocyanin green as a photosensitiser in treating SKMEL 188 human melanoma cells and S91 murine melanoma cells [38]. These results not only confirm the possibility of using PDT in treating melanoma but corroborate the results presented herein, i.e. that yield of singlet oxygen generation for both examined photosensitisers was sufficient to inhibit proliferation of melanoma cells. The higher yield of singlet oxygen production of the TPYR-PP compound might be in part responsible for the higher efficiency demonstrated by this compound, although higher concentration in cells confirmed by confocal microscopy is not without importance. The use of cationic liposomes as a carrier of porphyrins enabled their efficient transfer into cells. It has been known that the mode of transfer strongly influences subsequent localisation of photosensitiser in cells. Penetration of photosensitiser-containing liposomes into cells by endocytosis strongly increases photodynamic efficiency of the PDT agent [39]. In 2001, Damoiseau et al. [40] have observed an $85 \%$ proliferation inhibition of WiDr cells' following administration of liposome incorporated bacteriochlorin $a$ and irradiation of cultures with $10 \mathrm{~J} / \mathrm{cm}^{2}$. Only $40 \%$ inhibition was seen when photosensitiser was merely added alone to the medium. The observed improvement was probably the result of lack of aggregation of photosensitiser molecules administered in liposomal form. It is well known that only monomeric forms of photosensitiser exhibit high yield of singlet oxygen generation [41].

It is noteworthy that both porphyrin derivatives are highly photostable. Neither one undergoes photodegradation following irradiation doses used to investigate the PDT effect.

In order to assess photosensitising abilities of both C16TTP and TPYR-PP two methods were used: MTS test and clonogenic test. They allow differentiating between some aspects of cellular death. We conclude that neither compound shows "dark" cytotoxicity, however, both are 
strongly toxic for the transfected cell lines studied upon light irradiation. The progressive inhibition of proliferative capabilities was proportional to irradiation dose and time elapsed thereafter. It is difficult, however, to compare these results with literature data due to different origin of cell lines or the nature of photosensitisers.

Intracellular localisation study of C16-TTP and TPYRPP, performed using confocal microscopy, has shown that fluorescence appears initially in regions adjacent to cytoplasmic membrane, later becoming more pronounced in areas around nuclear membrane. These changes suggest that this is the result of translocation of either derivative towards nucleus and adjacent areas, involving mitochondria and endoplasmatic reticulum. In case of Photofrin II, after $4 \mathrm{~h}$ of incubation evenly distributed fluorescence can be seen throughout the cytoplasm. Differences in intracellular localisation between investigated compounds and Photofrin II are due to different chemical properties and a different translocation mechanism (diffusion vs. endocytosis).

Our results show that the mechanism of action for the studied compounds affects the coexisting processes of apoptosis and necrosis. The presented data are based on of morphological differentiation criteria between apoptotic and necrotic cells, as established by Lelli et al. [20]. They require confirmation by independent techniques such as flow cytometry, immunocytochemistry as well as biochemical studies. Nonetheless, analysis of the gathered data suggests that the manner of cell death following application of either one of the examined compounds depends on light irradiation dose used. In either case, when high dose $\left(15 \mathrm{~J} / \mathrm{cm}^{2}\right)$ was used the dominating effect was necrosis. Almost total inhibition of cellular proliferation was then observed.

\section{Conclusion}

Both studied porphyrin derivatives TPYR-PP (5-(4hydroxyphenyl)-10,15,20-tritolylpor) and C16-TTP (5-(4hexadecyloxyphenyl)-10,15,20-tri-pyridylporphyrin) were chemically well characterised. They are photodynamicly active, effectively inducing cell death when light activated, presumably due to the efficient generation of singlet oxygen. Singlet oxygen is produced with unit efficiency upon collision of the triplet of the compounds with ground-state oxygen. The phototoxicity towards cancer cells showed light-dose and cell line dependent characteristics. Such type of porphyrin derivatives seem to be promising agents for PDT treatment of neoplasms. Further quantitative data about stability, concentration, and retention in cells need to be gathered. In vivo use would probably require application of more sophisticated (for example: targeted) carriers.

\section{Abbreviations}

AO acridine orange

BSA bovine serum albumin
C16-TTP 5-(4-hydroxyphenyl)-10,15,20-tritolylporphyrin

DMF dimethylformamide

EB ethidium bromide

PDD photodynamic diagnostics

PDT photodynamic therapy

TLC thin-layer chromatography

TPYR-PP 5-(4-hexadecyloxyphenyl)-10,15,20-tri-pyridylporphyrin

NA numerical aperture

RT room temperature

\section{Acknowledgements}

This work has been supported by Internal Statutory Grant of Department of Solid State Physics from The University of Silesia. We are gratefully acknowledged to Anna Pasewicz for taking part in the synthesis of TPYR-PP and Carlos J.P. Monteiro for the careful sample purification. One author (C.S.) acknowledges FCT (Portugal) for Grant SFRH/BPD/13297/2003.

\section{References}

[1] T.J. Dougherty, C.J. Gomer, B.W. Henderson, G. Jori, D. Kessel, M. Korbelik, J. Moan, Q. Peng, Photodynamic therapy, J. Natl. Cancer Inst. 90 (1998) 889-905.

[2] A.P. Castano, T.N. Demidowa, M.R. Hamblin, Mechanisms in photodynamic therapy: Part I - photosensitisers, photochemistry and cellular localization, Photodiag. Photodyn. Ther. 1 (2004) 279293.

[3] Z. Luksiene, Photodynamic therapy: mechanism of action and ways to improve the efficiency of treatment, Medicina 12 (2003) 11371150.

[4] M.E. Milanesio, F.S. Moran, E.I. Yslas, M.G. Alvarez, V. Rivarola, E.N. Durantini, Synthesis and biological evaluation of methoxyphenyl porphyrin derivatives as potential photodynamic agents, Bioorg. Med. Chem. 8 (2001) 1943-1949.

[5] D.E. Dolmans, D. Fukumura, R.K. Jain, Photodynamic therapy for cancer, Nat. Rev. Cancer 3 (2003) 380-387.

[6] A.C. Moor, Signaling pathways in cell death and survival after photodynamic therapy, J. Photochem. Photobiol. B 57 (2000) 1-13.

[7] J. Morgan, A.R. Oseroff, Mitochondria-based photodynamic anticancer therapy, Adv. Drug Deliv. Rev. 49 (2001) 71-86.

[8] N.L. Oleinick, R.L. Morris, I. Belichenko, The role of apoptosis in response to photodynamic therapy: What, where, why, and how? Photochem. Photobiol. Sci. 1 (2002) 1-21.

[9] C.N. Zhou, Mechanisms of tumor necrosis induced by photodynamic therapy, J. Photochem. Photobiol. B 3 (1989) 299-318.

[10] E.S. Nyman, P.H. Hynninen, Research advances in the use of tetrapyrrolic photosensitisers for photodynamic therapy, J. Photochem. Photobiol. B 73 (2004) 1-28.

[11] R. Bonnett, Photodynamic therapy in historical perspective, Rev. Contemp. Pharmacother. 10 (1999) 1-17.

[12] R.R. Allison, G.H. Downie, R. Cuenca, X.H. Hu, C.J. Childs, C.H. Sibata, Photosensitisers in clinical PDT, Photodiag. Photodyn. Ther. 1 (2004) 27-42.

[13] X.D. Wang, B.W. Zhang, J.W. Bai, Y. Cao, X.R. Xiao, J.M. Xu, Light-induced electron transfer of porphyrin triad photoelectric conversion, J. Phys. Chem. 96 (1992) 2886-2891.

[14] S. Takagi, T. Yamamura, M. Nakajima, K. Ishiguro, Y. Kawanishi, S. Nihojima, H. Tsuchiya, Synthesis of amphiphilic porphyrins, Bull. Chem. Soc. Jpn. 54 (1981) 3879-3880. 
[15] M. Pineiro, A.L. Carvalho, M.M. Pereira, A.M.d'A. Rocha Gonsalves, L.G. Arnaut, S.J. Formosinho, Photoacoustic measurements of porphyrin triplet-state quantum yields and singlet-oxygen efficiencies, Chem. Eur. J. 4 (1998) 2299-2307.

[16] C.J.P. Monteiro, M.M. Pereira, M.E. Azenha, H.D. Burrows, C. Serpa, L.G. Arnaut, M.J. Tapia, M. Sarakha, P.W.-W.-Chung S. Nararatnam, A comparative study of water soluble 5,10,15,20tetrakis (2,6-dichloro-3-sulfophenyl)porphyrin and its metal complexes as efficient sensitizers for photodegradation of phenols, Photochem. Photobiol. Sci. 4 (2005) 617-624.

[17] Y. Yamazaki, M. Nango, M. Matsuura, Y. Hasegawa, M. Hasegawa, N. Oku, Polycation liposomes, a novel nonvirial gene transfer system, constructed from cetylatedolyethylenimine, Gene Ther. 7 (2000) $1148-1155$.

[18] J. Carmichael, W.G. DeGraff, A.F. Gazdar, J.D. Minna, J.B. Mitchel, Evaluation of a tetrazolium-based semiautomated colorimetric assay: assessment of chemosensitivity testing, Cancer Res. 47 (1987) 936-942.

[19] R.C. Duke, J.J. Cohen, Morphology and biochemical assays of apoptosis, Curr. Protein Immunol. 17 (Suppl. 3) (1992) 1-16.

[20] J.L. Lelli Jr., L.L. Becks, M.I. Dabrowska, D.B. Hinshaw, ATP converts necrosis to apoptosis in oxidant-injured endothelial cells, Free Radic. Biol. Med. 25 (1998) 694-702.

[21] R. BonnettChemical Aspect of Photodynamic Therapy, vol. 68-69, Gordon and Breach Science Publishers, New York, 2000, pp. 150-151.

[22] R. Bonnett, Photosensitisers of the porphyrin and phtalocyanine series for photodynamic therapy, Chem. Soc. Rev. 24 (1995) 1933.

[23] M.C. DeRosa, R.J. Crutchley, Photosensitised singlet oxygen and its applications, Coord. Chem. Rev. 233-234 (2002) 351-371.

[24] H.D. Burrows, L.G. Arnaut, J. Pina, J. Seixas de Melo, N. Chattopadhyay, L. Alcácer, A. Charas, J. Morgado, Characterisation of the triplet state of a fluorene-terthiophene alternating copolymer, Chem. Phys. Lett. 402 (2005) 197-201.

[25] R. Schmidt, C. Tanielian, R. Dunsbach, C. Wolff, Phenalenone, a universal reference compound for the determination of quantum yields of singlet oxygen $\mathrm{O}_{2}\left({ }^{1} \Delta_{\mathrm{g}}\right)$ sensitization, J. Photochem. Photobiol. A 79 (1994) 11-17.

[26] J.C. Scaino (Ed.), CRC Handbook of Organic Photochemistry, CRC Press, Boca Raton, FL, 1989.

[27] J.R. Hurst, J.D. McDonald, G.B. Schuster, J. Am. Chem. Soc. 104 (1982) 2065-2067.

[28] F. Wilkinson, W.P. Helman, A.B. Ross, Quantum yields for the photosensitized formation of the lowest electronically excited singlet state of molecular oxygen in solution, J. Phys. Chem. Ref. Data 22 (1993) 113-262.
[29] R. Bonnett, D.J. McGarvey, A. Harriman, E.J. Land, T.G. Truscott, U.-J. Winfield, Photophysical properties of meso-tetraphenylporphyrin and some meso-tetra(hydroxypheny)porphyrins, Photochem. Photobiol. 48 (1988) 271-276.

[30] S. Nonell, P.F. Aramendia, K. Heihoff, R.M. Negri, S. Braslavsky, J. Phys. Chem. 94 (1990) 5879-5883.

[31] F. Postigo, M. Mora, M.A. De Madariaga, S. Nonell, M.L. Sagristá, Incorporation of hidrofobic porphyrins into lipossomes: characterization and structural requirements, Int. J. Pharm. 278 (2004) 239254.

[32] W.N. Leung, X. Sun, N.K. Mak, C.M.N. Yow, Photodynamic effects of mTHPC on human colon adenocarcinoma cells: photocytotoxicity, subcellular localisation and apoptosis, Photochem. Photobiol. 75 (2002) 406-411.

[33] G. Jori, Tumour photosensitisers: approaches to enhance the selectivity and efficiency of photodynamic therapy, J. Photochem. Photobiol. B 36 (1996) 87-93.

[34] R.W. Redmond, J.N. Gamlin, A compilation of singlet oxygen yields from biologically relevant molecules, Photochem. Photobiol. 70 (1999) 391-475.

[35] L. Bourre, G. Simonneaux, Y. Ferrand, S. Thibaut, Y. Lajat, T. Patrice, Synthesis, and in vitro and in vivo evaluation of a diphenylchlorin sensitiser for photodynamic therapy, J. Photochem. Photobiol. B 69 (2003) 179-192.

[36] S. Banfi, E. Caruso, S. Caprioli, L. Mazzagatti, G. Canti, R. Ravizza, M. Gariboldi, E. Monti, Photodynamic effects of porphyrin and chlorin photosensitisers in human colon adenocarcinoma cells, Bioorg. Med. Chem. 12 (2004) 4853-4860.

[37] S. Nagata, A. Obana, Y. Gohto, S. Nakajima, Necrotic and apoptotic cell death of human malignant melanoma cells following photodynamic therapy using an amphiphilic photosensitiser, ATX-S10(Na) Lasers, Surg. Med. 33 (2003) 64-70.

[38] K. Urbanska, B. Romanowska-Dixon, Z. Matuszak, J. Oszajca, P. Nowak-Sliwinsk, G. Stochel, Indocyanine green as a prospective sensitizer for photodynamic therapy of melanomas, Acta Biochim. Pol. 49 (2002) 387-391.

[39] Y. Takeuchi, K. Ichikawa, S. Yonezawa, K. Kurohane, T. Koishi, M. Nango, Y. Namba, N. Oku, Intracellular target for photosensitization in cancer antiangiogenic photodynamic therapy mediated by polycation liposome, J. Control. Release 97 (2004) 231-240.

[40] X. Damoiseau, H.J. Schuitmaker, J.W. Lagerberg, M. Hoebeke, Increase of the photosensitizing efficiency of the Bacteriochlorin a by liposome-incorporation, J. Photochem. Photobiol. B 60 (2001) 50-60.

[41] L.E. Bennett, K.P. Ghiggino, R.W. Henderson, Singlet oxygen formation in monomeric and aggregated porphyrin $c$, J. Photochem. Photobiol. B 3 (1989) 81-89. 